Both macroscopically and microscopically we observed: (a) more severe atheromatous lesions in the animals treated with hyaluronidase than in those of the other groups, as already described by Cali and Scifter ${ }^{13-15}$; (b) a slight inhibition of the hyaluronidase by sodium salicylate in the animals treated with cholesterol, hyaluronidase and sodium salicylate, whereas no significant variations were observed in the animals treated with cholesterol and sodium salicylate.

Therefore, we bolieve it may be assumed: $(a)$ that high doses of sodium salicylate slightly inhibit the hyaluronidase only when the hyaluronic acid-hyaluronidase system is turned towards the hyaluronidase, as in the animals treated with cholesterol and hyaluronidase; it would be advisable to examine the relationship between this effect and the dose of salicylate; (b) that it is possible to confirm only in part what Guerra ${ }^{1}$ found in his experiments; (c) that there is not sufficient evidence to state, as Guerra did, that salicylate is effective in rhoumatic diseases because of its antihyaluronidase action. It might be considered this is only a part of the therapeutic efficiency of this drug. In this respect, on the other hand, it has been recently pointed out ${ }^{16-19}$ that other substances of the bradykinin group are important in the pathogenesis of rheumatic diseases and that sodium salicylate completely inhibits the action of these substances.

$$
\begin{aligned}
& \text { G. B. Rossi } \\
& \text { E. Caccavale } \\
& \text { L. Coscia Porrazzi }
\end{aligned}
$$

Institute of Pathological Anatomy,

$$
\text { University of Naples. }
$$

${ }^{1}$ Guerra, F., J. Pharm. Exp. Ther., 87, 193 (1945). 2 Dorfmann, A., Reimers, J., and Ott, M. L., Proc. Soc. Exp. Biol. Med.,
64, 357 (1947).

${ }^{3}$ Ferrari, W., Costa, E., and Pellegrini, P., Arch. Sci. Biol., 33, 48 (1949).

- Parvis, D., and Marazzi, E., Il Farmaco, 9, 224 (1954).

${ }^{5}$ Parvis, D., and Marazzi, E., Il Farmaco, 11, 239 (1956).

- Schiavetti, L., and Ferraris, P., Reumatismo, 7, 70 (1955).

'Swyer, G. I. M., Biochem. J., 42, 28 (1948).

${ }^{8}$ Swyer, G. I. M., Biochem. J., 42, 32 (1948).

- Beiler, J. M., and Martin, G. J., J. Biol. Chem., 171, 507 (1947).

${ }^{10}$ Beiler, J. M., Breudel, R., and Martin, G. J., J. Amer. Pharm. Assoc., 43, 480 (1954).

${ }^{12}$ Pike, R. M., Science, 105, 391 (1947).

${ }^{23}$ Busing, H. K., Arzn. Forsch., 5, 320 (1955).

${ }^{13}$ Call, A., Riv. Anat. Pat. Oncol., 5, 6 (1953).

${ }^{14}$ Cali, A., Quad. No. 17, Sez. Perug. Soc. It. Biol. Sper., Perugia Simonelli (1956).

${ }^{15}$ Seifter, J., Baeder, D. H., Beckfield, W. J., Sharma, G. P., and Ehrich, W. E., Proc. Soc. Exp. Biol. Med., 83, 468 (1953).

${ }^{16}$ Spector, W. G., and Willoughby, D. A., Nature, 196, 1104 (1962).

${ }^{17}$ Bhoola, K. D., Calle, J. D., and Schachter, M., J. Physiol., 152, 75 (1960)

${ }^{18}$ Northover, B. J., and Subramanian, G., Brit. J, Pharmacol., 17, 107 (1961).

${ }^{19}$ Spector, W. G., and Willoughby, D. A., J. Physiol. (in the press), quoted by ref. 16 .

\section{Elevation by Propynylamines of Rat Tissue Norepinephrine-levels and Reserpine Antagonism in Mice}

The hydrochlorides of 2-propynylamine, di-2-propynylamine, and tri-2-propynylamine wore tested in several systems for monoamine-oxidase inhibition. The 2-propynylamines were supplied through the courtesy of Dr. Alfred Bader of the Aldrich Chemical Co.

Norepinephrine-levels were determined in the pooled brains and hearts of groups of 5 rats each injected intraperitoneally with $10 \mathrm{mg} / \mathrm{kg}$ and $40 \mathrm{mg} / \mathrm{kg}$ of 2-propynylamine hydrochloride once daily for 4 days. The tissues were extracted in duplicate by the procedure of Shore and Olin ${ }^{1}$ and norepinephrine determined by the method of Von Euler and Floding ${ }^{2}$ using a spectro-photofluorometer. The $10 \mathrm{mg} / \mathrm{kg}$ dose of 2 -propynylamine hydrochloride elevated brain- and heart-levels of norepinophrine to 151 per cent $(146-156)$ and 122 per cent

\begin{tabular}{|c|c|c|c|c|}
\hline \multicolumn{5}{|c|}{ PYNYLAMINES IN MICE GIVEN RESERPINE } \\
\hline Compound & $\begin{array}{c}\text { Dose } \\
(\mathrm{mg} / \mathrm{kg}, \\
\text { intra- } \\
\text { peritoneal })\end{array}$ & $\begin{array}{l}\text { Time } \\
\text { before } \\
\text { reserpine }\end{array}$ & $\begin{array}{c}\text { Degree } \\
\text { of } \\
\text { ptosis }\end{array}$ & $\begin{array}{c}\mathrm{mg} / \mathrm{kg} \text { metrazole } \\
\text { required to } \\
\text { cause seizures } \\
\text { (mean } \pm S . E .)\end{array}$ \\
\hline None & - & 一 & 0 & $12 \pm 1 \cdot 0$ \\
\hline Reserpine & 4 & - & & \\
\hline+2 -propy & 50 & 9 days & $2 \cdot 3$ & $11 \cdot 5$ \\
\hline hydroch & 50 & $2 \mathrm{~h}$ & 0.8 & 13.8 \\
\hline$+\mathrm{Di}$ & & $\begin{array}{l}21 \\
21\end{array}$ & $\begin{array}{l}3 \cdot 4 \\
2 \cdot 4\end{array}$ & $\begin{array}{r}8 \cdot 8 \pm 3 \cdot 5 \\
12 \cdot 5+2 \cdot 8\end{array}$ \\
\hline hys & 00 & 2 & 3.9 & $5.3 \pm 0.5$ \\
\hline + Tri & 100 & $2 \mathrm{~h}$ & $3 \cdot 1$ & $11 \cdot 0 \pm 2 \cdot 0$ \\
\hline hydrochloride & 50 & $2 \mathrm{~h}$ & 3.8 & $7 \cdot 8 \pm 1 \cdot 0$ \\
\hline
\end{tabular}
(114-130) of the levels found in control animals. The $40 \mathrm{mg} / \mathrm{kg}$ dose raised brain and heart norepinephrine-
Table 1. Anti-ptotic AND Anti-extensor Seizure EfFects of 2-Pro-

levels to 185 per cent (170-200) and 130 per cent (128-133) of the control values.

The monoamine-oxidase activity of the propynylamines was examined in mice by their ability to reduce the reserpine-induced ptosis and to antagonize the facilitatory effect of reserpine on tonic-extensor seizures ${ }^{3}$. Groups of 5 mice each were given the propynylamine compounds by intraperitoneal injection and $2 \mathrm{~h}$ or more later were given $4 \mathrm{mg} / \mathrm{kg}$ of reserpine, in 5 per cent ascorbic acid solution, by intraperitoneal injection. One group of mice without drug treatment and one group given reserpine alone were used in each experiment as controls. A 0.5 per cent solution of 'Metrazol' was used to produce tonicoxtensor seizures by intravenous infusion. Table 1 shows the activities of the 2-propynylamines in both tests. At the $50 \mathrm{mg} / \mathrm{kg}$ dose-level of 2-propynylamine the antiroserpine activity, as measured by the 'Metrazol' test, lasted for 9 days. Di-2-propynylamine and tri-2-propynylamine both had anti-reserpine activity but were less active than 2-propynylamine. The 2-propynylamines alone did not cause any marked retraction of eyelids or produce an anti-convulsant effect on tonic-extensor seizures at the doses used.

2-Propynylamine is a potent compound in raising rat tissue norepinephrine-levels; furthermore, 2-propynylamine antagonizes the effects of reserpine in mice.

\section{J. R. Mclean} G. Chen

Departments of Pharmacology and Chemistry,

Parke, Davis and Co., Research Laboratories, Ann Arbor, Michigan.

1 Shore, P. A., and Olin, J. S., J. Pharmacol. Exp. Therap.,122, 295 (1958). Von Euler, U. S., and Floding, I., Acta Physiol. Scand., 118, 45, Suppl. 33. (1955).

${ }^{3}$ Chen, G., and Bohner, B., J. Pharmacol., 131, 179 (1961).

\section{HEMATOLOGY}

\section{Absence of Lysolecithin Formation in $\mathbf{C}^{\prime}{ }_{3}$-deficient Rabbit Serum}

RECENTLY, Fischer and Haupt have shown ${ }^{1-3}$ that the activation of complement in human, guinea pig, rabbit, and pig sorum is paralleled by an increase in lytic activity due to an inerease of lysolecithin. In these experiments complement was activated by the addition of soluble antigen-antibody-complexes or by the addition of heataggregated human $\gamma$-globulin. Complement activity was determined using sensitized sheep erythrocytes, while the lytic activity of lysolecithin was detormined in lipid extracts of the same sera by the method of Schubothe and $\mathrm{Fok}^{4}$ (see also legend to Table 1).

Further evidence for the dependence of lysolecithin formation on the presence of whole complement might be obtained by demonstrating that rabbit sera lacking $\mathrm{C}_{3}{ }_{3}$ are unable to form lysolecithin.

A strain of $\mathrm{C}^{\prime}{ }_{3}$-deficient animals (Freiburg $R$ 3-Stamm) was described recently and investigated by $K$. and $U$. Rother ${ }^{5,6}$. In the hæmolytic system serum of $\mathrm{C}^{\prime}{ }_{3}$-deficient animals behaves in the same way as does rabbit sorum depleted of $\mathrm{C}^{\prime}$ by treatment with 'Zymosan'. Complement activity can be restored by adding any preparation which contains $\mathrm{C}_{3}^{\prime}$. 